\title{
Web Globalization and Its Possible Consequences on Usage of Different Creative Accounting Techniques
}

\author{
Boris Kollar ${ }^{1, *}$ \\ ${ }^{1}$ University of Zilina, FPEDAS, Department of Economics, Univerzitna 1,010 26 Zilina, Slovakia
}

\begin{abstract}
.
Research background: The paper is oriented on influence analysis of globalization on usage of different techniques of creative accounting and its development. The concept of creativity and accounting in together has logical background. Creativity is generally perceived as a positive thing. It is a certain creativity and originality created by the individual. Among these techniques, the paper deals with earnings management and what differs it from fraudulent behavior. The first part deals with definition of earnings management and comparison of different approaches. The second part outlines the major differences and boarders between earnings management and fraud from theoretical point of view with the usage of multiple views from different authors. Third part deals with different forms of earnings management. The last part discusses motives behind the usage of earnings management by managers and impact of globalization on this decision making.

Purpose of the article: To describe motives behind earnings management usage and potential new directions of these motives under the conditions of continuous internalization and globalization.

Methods: The paper is built on the methods of formal logic. The most important one for the purpose of this article is descriptive method. Among others, there are analysis, graphic method, comparison and synthesis.

Findings \& Value added: Comprehensive overview of the earnings management definition, its forms and motives behind its usage.
\end{abstract}

Keywords: earnings management, creative accounting. globalization, financial statements, motivation

JEL Classification: $G 20 ; G 10 ; O 10$

\section{Introduction}

Earnings management as a concept is not new. In 1989, Schipper was one of the first authors to define earnings management and referred to it in his definition as a purposeful

${ }^{*}$ Corresponding author: boris.kollar@,fpedas.uniza.sk 
intervention in the external financial reporting process with the intention of obtaining personal gain. [1]

Among popular definitions, we can include the definition by Healy and Wahlen. Profit management occurs, when managers use judgments and conjectures in financial reporting in a way that allows financial results to be changed to give investors a distorted view of the company's financial situation, or to affect the output of contracts depending on the amount of the reported accounting results. [2] Although some organizations also made their own definitions like the United States Securities and Exchange Commission (SEC), in its 1999 Annual Report. It refers to earnings management as an aggressive practice used by listed companies, which involves the application of various forms of fraudulent techniques aimed at distorting a company's real financial results to achieve its own desired objectives. [3] Profit management is considered to be the active manipulation of a company's financial results in order to show the company's economic situation in the best possible light." [4,5]

Ortega and Grant defined earning management as "the active manipulation of earnings in order to reach its required level". [6] Earnings management often requires the practice of reducing and withholding profits in prosperous years, in order to take advantage of profits made in a weaker period. This popular form of profit reporting is also known as income smoothing. [6] Scott offers another possible definition. According to him the term earnings management means the choice of accounting policy, resp. policies to business managers so that specific goals can be achieved. [7]

Earnings management as purposeful and legal management of decision-making and reporting with the aim of achieving stable and predictable results. [8] This definition contains unambiguous and essential information that it is a legal management of profit, although the degree of creativity and adjustment of financial statements is in the hands of the manager, respectively. another internal employee of the company and these phenomena cannot be denied.

Ronen and Yari provided a general definition of earnings management. It focuses on management, specifically its steps to influence the interpretation of reported gains, with earnings management including intentional steps to influence reported gains as well as interpretation. [9]

The following alternative definitions may be also found in Earnings Management by the same authors. [9]

Table 1. Alternative approach to earnings management.

\begin{tabular}{|c|c|c|}
\hline Black earnings management & Grey earnings management & White earnings management \\
\hline $\begin{array}{c}\text { In this case, earnings } \\
\text { management is based on the } \\
\text { application of such practices } \\
\text { and procedures that seek to } \\
\text { distort or reduce the } \\
\text { transparency of financial } \\
\text { statements }\end{array}$ & $\begin{array}{c}\text { According to this } \\
\text { categorization, earnings } \\
\text { management is the choice of } \\
\text { accounting method based on an } \\
\text { opportunistic approach (an } \\
\text { effort to maximize utility) or an } \\
\text { approach based on economic } \\
\text { efficiency }\end{array}$ & $\begin{array}{c}\text { Approach based on the } \\
\text { flexibility of the accounting } \\
\text { method choice, while the level } \\
\text { of flexibility allows to indicate } \\
\text { information of a private nature } \\
\text { about the future cash flows in } \\
\text { the company }\end{array}$ \\
\hline \multicolumn{2}{|c|}{ Significant Authors } \\
\hline $\begin{array}{c}\text { Schipper (1989) } \\
\text { Levitt (1998) }\end{array}$ & Fields, Lys and Vincent (2003) \\
Tzur and Yari (1999) & $\begin{array}{c}\text { Ronen and Sadan (1981) } \\
\text { Suh (1990) } \\
\text { Demski (1998) } \\
\text { Beneish (2001) }\end{array}$ \\
\hline
\end{tabular}




\section{Methods}

This part presents the difference between earnings management and fraud. In 1987 Merchant argued that fraud is an act that falsifies or alters documents, removes transactions from records or falsifies transactions, or conceals important information, including manipulation. with accounts relating to, resp. which are associated with the interpretation of generally accepted accounting principles (GAAP).

Earnings management can take place through aggressive accounting or conservative accounting under GAAP, which usually occurs at the end of the fiscal year, e.g. by reducing or increasing the estimate for provisions. However, it can also take place through aggressive or conservative economic decisions of managers, who can make these decisions at any time during the fiscal year and thus affect the cash flow of the company, e.g. by speeding up or delaying individual sales, which will affect the company's sales revenues. [10] Earnings management may also result in an increase or decrease in reported profit, which may be considered harmful, if it contributes to minimizing the value of the business, but may also be considered beneficial, if it allows more information about the business to be obtained in the future.

Despite this behaviour, earnings management does not constitute a breach of accounting policies. In contrast to fraud, which consists of a breach of generally accepted accounting principles, e.g. ignoring certain GAAP requirements or recording fictitious or unrealized sales. Managers may commit fraud during, or after the financial year to increase, or decrease reported profit. Fraud usually follows aggressive accounting and has a detrimental effect on the company as well as on the company's interest groups. [11]

For better understanding of the differences between earnings management and fraud, we present Table 2, which is based on Dechow and Skinner. [12]

Table 2. Difference between earnings management and fraud.

\begin{tabular}{|c|c|}
\hline Choice of accounting & Type of reporting \\
\hline \multicolumn{2}{|c|}{ Within the rules of GAAP } \\
\hline $\begin{array}{c}\text { the costs of asset depreciation and restructuring } \\
\text { are overstated } \\
\text { reserves are formed too aggressively }\end{array}$ & $\begin{array}{c}\text { Conservative accounting } \\
\text { the result is a conservative profit characterised as } \\
\text { an understatement }\end{array}$ \\
\hline neutral operations yielding standard profit & $\begin{array}{c}\text { Neutral accounting } \\
\text { This case does not assume earnings management }\end{array}$ \\
\hline $\begin{array}{l}\text { Reserves for abandoned claims are understated } \\
\text { Using of reserves is too aggressive }\end{array}$ & $\begin{array}{c}\text { Aggressive accounting } \\
\text { The result is aggressive profit characterise with } \\
\text { overstatement }\end{array}$ \\
\hline \multicolumn{2}{|c|}{ Violation of GAAP } \\
\hline $\begin{array}{c}\text { sales are recorded before their implementation } \\
\text { inventory is overstated by recording fictitious } \\
\text { inventory }\end{array}$ & fraud \\
\hline
\end{tabular}

In terms of earnings management's forms, we can consider two forms, namely the socalled Real Earnings Management (REM) or Accrual-based Earnings Management (AEM).

The first option is chosen by managers to achieve the desired goal of profit through activities in the company. When practicing REM, the company's activities differ from the company's normal activities performed by managers, with the aim of misleading certain interest groups. [13]

In particular, REM has the advantage over AEM in the ability not to be easily detected by regulators or auditors, which results in an easier achievement of the required target profit. However, it is also necessary to inform about the disadvantage of REM, which is a 
worse impact on the future cash flow of the company. For this reason, interest groups must also anticipate such manipulation, as it may jeopardize the company's survival. Managers have different considerations when choosing forms of earnings management, but managers also tend to use both forms to achieve the desired or specified value of profit. [14]

According to Roychowdhury, earnings management can be done in three different ways. The first one is the manipulation in the area of sales. The second one is the manipulation aimed at reducing discretionary expenditure and the last one is the manipulation of the production process, in the sense of overproduction, thus reducing unit fixed costs. [13]

Ferdawati declared that REM has a positive effect on the value of the company. The market was unable to detect this manipulation practice, which leads to misjudgement and incorrect assessment of the company in the market. [15]

On the other hand, some authors state that REM causes a negative impact on the value of the company. [16] Their finding is in line with a statement made by Roychowdhury mentioned above by stating that REM may reduce the value of a company, as this form of earnings management may increase profits in the current (short-term) period, but has a very adverse effect on future corporate cash flow. This is the main difference between REM and AEM (AEM only expects a change in accruals). This worsened impact on the company will make the market more anticipative to a possible form of manipulation through actual activities in the company, thus giving the company a negative reaction if it identifies it as a REM practicing company. [17] The second option is to practice earnings management with the use of accounting principles, which is called accounting earnings management (AEM). AEM is based on accruals, the purpose of which is to capture revenue and expenses truthfully in the period in which they are incurred. Characteristic of AEM is that it has inverted (reverse)

accruals in the period following after manipulation. An increase in profit in a given period will result in a decrease in profit in a future period. Conversely, a reduction in the current profit generated by the accrual method will result in an increase in profit in the future. As already mentioned, AEM does not affect the cash flow of the company. [18] Accruals can be divided into two groups, non-discretionary and discretionary. The non-discretionary component is determined by the normal economic conditions of the company. [19]

The discretionary component consists of accruals, ie it is not regulated by the manager's contract and represents only the choice of approach by the manager. Based on the above, it can be said that the discretionary component, resp. discretionary accruals are the result of managerial opportunism. Several authors found out, that AEM performed by managers led to market introduction and a positive impact on the value of the company. [20]

Table 3 summarizes the basic differences between the various forms of EM.

Table 3. Differences between REM and AEM.

\begin{tabular}{|c|c|c|c|}
\hline & $\begin{array}{c}\text { Realisation made } \\
\text { through }\end{array}$ & Usage & Impact on cash flow \\
\hline REM & operational decisions & financial statements & direct \\
\hline AEM & accounting principles & operating activities & indirect \\
\hline
\end{tabular}

\section{Results and Discussion}

Motivation is one of most important aspects related to earnings management. There are many motives leading to the practice of earnings management in companies and they are quite different. Several general motives or stimuli have already been presented in the introduction part of article. In this part, we introduce other set of motives, that we consider important to know. We will start with the area of social and political costs, which managers 
try to minimize through a certain selection in the financial statements, especially in order to prevent interventions and regulation by the government in the field of tax laws.

Watts, Zimmerman and Monem among others, state that companies are more likely to choose revenue-reducing manipulation to reduce political costs, because favourable accounting numbers may attract regulatory intervention. Managers are looking for ways to avoid tax obligations by practicing earnings management, so they do not provide complete information to the government bodies, as the numbers recorded in the accounts are the basis for calculating the tax. $[20,21]$

Another category of the motives are the ones associated with the characteristics of the company. Although some studies document that company size has an impact on earnings management behaviour. Other authors however do not confirm such an impact. [22]

In the Chinese economy, earnings management was not practiced to adjust the tax base, but the motive for its implementation was the need to meet the condition regarding the accounting rate of return on equity (ROE), as only those companies that were able to meet the condition of reporting ROE in the range of $10 \%-11 \%$ within three following years, were qualified to perform on the stock exchange. [23]

According to Demerijan, earnings management is more expected in small companies, because these have less predictable activities and also their business is less diversified. Similarly, managers of large companies have opportunities to manipulate profits due to the number of transactions and complicated activities. [24]

It is difficult to distinguish the behaviour of small and large companies in earnings management, because both types of companies face pressure to keep EM at an optimal level. Table 4 captures some other types of motives, including their earnings management assumptions, as they were described by Mulford and Comiskey. [25]

Table 4. Motives behind earnings management usage.

\begin{tabular}{|c|c|}
\hline $\begin{array}{c}\text { Assumption } \\
\begin{array}{c}\text { achieved profit is lower than was determined by } \\
\text { the market on the basis of the forecast of the } \\
\text { development of the economic result }\end{array}\end{array}$ & to avoid a possible fall in stock prices \\
\hline $\begin{array}{c}\text { the company is preparing for the first public } \\
\text { offer of shares }\end{array}$ & $\begin{array}{c}\text { Mresent the results in the best possible light so } \\
\text { that the market price of the stock is maximized }\end{array}$ \\
\hline $\begin{array}{c}\text { high losses due to restructuring and related costs } \\
\text { have been accrued in the past in order to report } \\
\text { better results }\end{array}$ & $\begin{array}{c}\text { use of the overestimated part in future periods } \\
\text { and contractual obligation }\end{array}$ \\
\hline $\begin{array}{c}\text { the company is close to a breach of a contractual } \\
\text { the achieved profit is higher or lower than the } \\
\text { long-term sustainable trend determined by the } \\
\text { company's management }\end{array}$ & $\begin{array}{c}\text { Avoid the negative reaction of investors to the } \\
\text { differences between the achieved result of the } \\
\text { company and the expected trend of profit } \\
\text { of a contractual obligation such as e.g. late } \\
\text { charges }\end{array}$ \\
\hline $\begin{array}{c}\text { chelopment. Minimize profit volatility against a } \\
\text { long-term goal. }\end{array}$ \\
change of the top management of the company \\
$\begin{array}{c}\text { Application of large depreciation immediately } \\
\text { after the arrival of new managers in order to } \\
\text { mitigate future results and transfer responsibility } \\
\text { to the previous management. }\end{array}$ \\
\hline
\end{tabular}




\section{Conclusion}

Globalization as a whole and Covid 19 pandemic nowadays puts high level of pressure on managers of companies. The decision making in many cases is influenced by drastic drops in earnings. It is therefore very important to concentrate on earnings management in this period to be able to survive without major consequences. Companies tend to make drastic changes in management and to make drastic cuts in their budgets during crisis like this. It is quite possible that companies will change their attitude and turn even faster to digital technologies. The well applied usage of Big data may have positive impact on earnings. [26]

The article offers mix of several interesting opinions and ideas from various authors from different countries from all over the world. It was mainly focused on concept of creativity and accounting in together. Among other techniques, the paper dealt with earnings management and what differs it from fraudulent behaviour. The first part dealt with various definitions of earnings management and comparison of different approaches. The second part outlined the major differences and boarders between earnings management and fraud. This was done mainly from theoretical point of view with the use of definitions made by several different authors. Third part dealt with different forms of earnings management in short. The last part discussed major motives behind the usage of earnings management by managers nowadays and impact of globalization on this decision making.

In the future, the research should be oriented on earnings management and the techniques used during Covid 19 pandemic. Decision making will surely differ from country to country despite globalization. Major impact on this fact will have the ability of Asian countries to deal with the pandemic better than the traditional western economics. As a result of this, continuous growth of Asian companies and their market shares may be expected. This will put huge pressure on managers of European and American brands to overcome this situation without fraudulent behaviour, but with effective investments and competent management of earnings.

have special significance.

The paper is an output of the science project VEGA 1/0210/19 Research of innovative attributes of quantitative and qualitative fundaments of the opportunistic earnings modelling which authors gratefully acknowledge.

\section{References}

1. Mahjoub, I., Miloudi, A. (2015). Earnings management: A review of literature. Conference: Euro and the European Banking System: Evolutions and challenges. University of IASI.

2. Healy, P.M., Wahlen, J.M. (1999). A review of the earnings management literature and its implications for standard setting. Accounting Horizons, 13(4).

3. SEC. 1999. SEC Annual report 1999. https://www.sec.gov/pdf/annrep99/ar99full.pdf.

4. Mulford, CH.W., Comiskeey, E.E. (2002). The financial numbers game: Detecting Creative Accounting Practices. New York: Willey.

5. Kramarova, K., Valaskova, K. (2020). Application of chosen fraudulent detection technique in the slovak business environment. SHS Web of Conferences, 74, p. 1019.

6. Ortega, W.R., Grant, G.H. (2003). Maynard manufacturing: An analysis of GAAP based and operational earnings management techniques. Strategic Finance, 85(1), 50.

7. Scott, W.R. (2003). Financial accounting theory. 3. edition. Toronto, Ontario: Prentice Hall. 
8. Mckee, T.E. (2005). Earnings management: An executive perspective. London: Thomson.

9. Ronen, J., Yaari, V. (2008). Earnings management. Emerging insights in theory, practice and research. New York: Springer.

10. Majercak, P., Cisko, S., Majercakova, E. (2013). The impact of theory of constraints on the management accounting. Proceedings of the 7th International Days of Statistics and Economics (pp. 894-904). 7.

11. El Diri, M. (2018). Introduction to earnings management. Springer International Publishing AG. 113.

12. Dechow, P.M., Skinner, D.J. (2000). Earnings management: Reconciling the views of accounting academics, practitioners, and regulators. Accounting Horizons, 14(2), 235250.

13. Roychowdhury, S. (2006). Earnings management through real activities manipulation. Journal of Accounting and Economics, 42(3), 335-370.

14. Zang, A.Y. (2012). Evidence on the trade-off between real activities manipulation and accrual-based earnings management. The Accounting Review, 87(2), 675-703.

15. Ferdawati, F. (2009). The effect of real earnings management on company value. Journal of Accounting \& Management, 4(1), 59-74.

16. Kramarova, K., Valaskova, K. (2015). Globalization and transfer pricing: brief analysis of the legislation in the Slovak republic. Proccedings of the $15^{\text {th }}$ International Conference Globalization and Its Socio-Economic Consequences (pp. 353-361). Rajecke Teplice, Slovak Republic, 7.

17. Kovacova, M., Kliestik, T., Valaskova, K., Durana, P., \& Juhaszova, Z. (2019). Systematic review of variables applied in bankruptcy prediction models of Visegrad group countries. Oeconomia Copernicana, 10(4), 743-772.

18. Michalkova, L., Michalikova, K. F. (2020). Is the value of the new business tax shield lower? comparative study of international valuation methods. SHS Web of Conferences 74, p. 1022.

19. Xiong, Y. (2006). Earnings management and its measurement: A theoretical perspectives. Journal of American Academy of Business, 9(1), 214-219.

20. Monem, R. (2003). Earnings management in response to the introduction of Australian gold tax. Contemporary Accounting Research, 20(4), 747-774.

21. Watts, L.R., Zimmerman, J.L. (1986). Positive accounting theory. Pearson.

22. Siregar, S.V., Utama, S. (2008). Type of earnings management and the effect of ownership structure, firm size, and corporate - governance practices: Evidence from Indonesia. The International Journal of Accounting, 43(1), 1-27.

23. Haw, I. et al. (2010). Market consequences of earnings management in response to security regulations in China. Contemporary Accounting Research, 22(1).

24. Demerjian, P. et al. (2012). Managerial ability and earnings quality. Accounting Review. Sarasota: American Accounting Association.

25. Mulford, CH.W., Comiskey, E.E. (2002). The financial numbers game: Detecting Creative Accounting Practices. New York: Willey.

26. Bratu, Sofia (2019). Algorithmically constructed identities: networked digital technologies, dynamic behavioral big data collection, and automated decision-making. Contemporary Readings in Law and Social Justice, 11(2), 49-55. 